\title{
CURRENT PROBLEMS IN THE SOUTH-MORAVIAN RURAL LANDSCAPE
}

\author{
Antonín Vaishar ${ }^{1}$, Lenka Jakešová ${ }^{2}$ Miloslava Náplavová ${ }^{3}$
}

Received 14 July 2009; Accepted 16 December 2011

\begin{abstract}
Permanent development trends of the South-Moravian landscape are discussed. Four groups of impacts are observed: changes of agricultural using of the landscape, changes from the agricultural to other ways of utilization, stressing the landscape protection and influences of tourism. The changes in agricultural production occur in the less productive areas in the northern part of the region. Big changes were evoked by residential, commercial and industrial suburbanization in the hinterlands of Brno. About 1,300 rural brownfields can be found in the region. Wind power-plants form a new element in the landscape. The landscape protection has increased within EU. South Moravian landscape itself is the main offer for the tourism.
\end{abstract}

Keywords: landscape, agriculture, landscape protection, sustainability, countryside, tourism, South Moravia

Souhrn: $\vee$ příspěvku jsou diskutovány současné trendy vývoje venkovské krajiny jižní Moravy. Jsou vyčleněny čtyři druhy změn: změny zemědělského využití krajiny, změny od zemědělského $k$ jinému využití, důraz na ochranu krajiny a vlivy cestovního ruchu. Změny $v$ zemědělském využití jsou pozorovány $v$ méně produktivních oblastech severní části kraje. Velké změny byly vyvolány rezidenční, komerční a průmyslovou suburbanizací v zázemí Brna. V regionu je na 1300 rurálních brownfields. Nový prvek v krajině vytvářejí větrné elektrárny. Ochrana krajiny se pod vlivem EU zvyšuje. Jihomoravská krajina je hlavní turistickou nabídkou regionu sama o sobě.

Klíčová slova: krajina, zemědělství, ochrana krajiny, udržitelnost, venkov, cestovní ruch, jižní Morava

\section{Introduction}

The rural landscape covers a majority of the Earth's surface (Tapiador 2008). The countryside and the rural landscape have recently gained new significance. The rural landscape is generally considered to be the opposite of the urban landscape. Traditionally it has been utilized mainly for primary production branches, particularly agriculture and forestry as well as mining. Although

\footnotetext{
${ }^{1}$ Doc. RNDr. Antonín Vaishar, CSc., Ústav aplikované a krajinné ekologie Agronomické fakulty Mendelovy university v Brně, Zemědělská 1, 61300 Brno, Czechia, e-mail: antonin.vaishar@mendelu.cz

2 Ing. Lenka Jakešová, Ústav aplikované a krajinné ekologie Agronomické fakulty Mendelovy univerzity $v$ Brně, Zemědělská 1, 61300 Brno, Czechia, e-mail: lenka.jakesova@mendelu.cz

${ }^{3}$ Ing. Miloslava Náplavová, Ústav aplikované a krajinné ekologie Agronomické fakulty Mendelovy univerzity v Brně, Zemědělská 1, 61300 Brno, Czechia, e-mail: miloslava.naplavova@mendelu.cz
} 
the economic importance of primary activities has significantly declined over the past decades, the landscape-forming role of agriculture, forestry and water management is irreplaceable. The rural landscape is an integral part of South Moravia's image, as well as part of its values.

Recently however the rural landscape has been facing new, significant pressures. This is, on the one hand, a consequence of technological development and its social effects, and on the other hand, it is a consequence of opening up to the world and globalization since political liberalization in 1989. Boundary conditions for rural landscapes in Europe such as globalization, climate change, claims to land use etc. are subject to a constant, dramatic change (Wiggering et al. 2010).

In the hinterlands of large and, to some degree, of medium cities, suburbanization has led to the creation of a semi-urban landscape, in which there is no clear divide between the city and the countryside. However, even the more distanced countryside must adjust to pressures on recreational use and on the situation of transportation infrastructure and industrial sites, as well as from municipal waste dumps. The landscape has even begun to be perceived as endangered heritage and has begun to be a policy subject (Palang et al. 2004). Sometimes the rural landscape is even attributed a mystical significance (e.g. Wylie 2003).

On the other hand growing attention has been paid to large-scale as well as small-scale landscape protection. National parks, protected landscape areas and nature reserves have been created. The South Moravian landscape features the Lednice-Valtice area as well, whose cultural landscape is a part of the UNESCO world heritage list. The NATURA 2000 network was created within the framework of a European convention. Legislation forms the background for the formation and conservation of elements of ecological stability. In the developed world, protection of the rural landscape is an integral part of regional planning (Woods 2005). In the market economy nature and landscape conservation sometimes come into conflict with business interests and activities.

The aim of this article is to map out the current state of the South Moravian Region's landscape, to outline the basic trends in current changes and to discuss future development in regards to the effects of globalization. Of course, the globalization manifests itself through economy, mobility, values. The landscape is impacted by globalization derivative by mediation of the mentioned features. The question of the relationship between the identity of rural regions and globalization is also equally interesting. South Moravia has one peculiarity in this area, i.e. its living folk traditions combined with its wine culture. The globalization manifests itself by general migration of younger population from rural localities who seek jobs in cities, often leaving older, unsupported family member behind. Inversely, people flow into rural areas because of global counter-urbanization (Giarchi 2007).

\section{The landscape and its current changes}

The landscape is a selected part of the Earth's surface with a typical combination of natural and cultural elements and characteristic scenery. Topography, soil, water, climate, vegetation cover, fauna and humankind are the basic components. Landscapes are a spatially-temporal fabric of interactions between man and his environment. The landscape is connected with dwelling, primary and other economic activities, leisure, environment. By such a way landscape is also a very central concept in contemporary human geography (Soini 2004). Multifunctionality of landscape in connection with its sustainability is widely discussed (Helming and Wiggering 2003, Mander, Wiggering and Helming 2007).

In our paper we concentrate mainly on the rural landscape. The Central European landscape has been cultivated for thousands of years. The result is that an absolute majority of its area is a cultural landscape that has been transformed by humankind for its needs. Although over the last centuries the portion of landscape used for building settlements and infrastructure, or mining, as well as for bodies of water, has grown, the largest portion of the land is still used for primary production, particularly agriculture and forestry. Therefore even the current changes taking place in the landscape of South Moravia are the results of changes in agriculture and forestry. 
These changes are on the one hand general - a result of technological development - while on the other hand they are a result of changes in the management system relative to the transformation from a centrally planned economy to a market one (Blacksell 2010). Other changes though are related to suburbanization, which is changing the rural landscape surrounding large and medium cities (Antrop 2004, Harmin and Marcucci 2008) and the development of the global tourism industry, which is partially aimed at the rural landscape (e.g. Clout 2006), including the naturally based and educational eco-tourism (Hill and Gale 2009).

Bičík and Jančák (2003) have addressed changes in the rural landscape during the transformation period in Czechia. Flekalová and Trnka (2007) have dealt with evaluating the changes in South Moravia's rural landscape using Hustopeče area as an example. Their paper has methodological significance for landscape evaluation on a larger scale. Similar studies have been written in other post-socialist countries, some of which of course - in particular Poland (Łowicki and Mizgajski 2005) - have a markedly different base relative to different agricultural situations.

The potential and consequences of common European policy and support from European programs are frequently the topic of study (e.g. Kopecká 2004). The fact that agriculture's function has changed from production to landscape maintenance (Potter 1986) is extremely important. In Europe, a large amount of attention is paid to changes in the landscape, which is expressed in the European Landscape Convention, approved in Florence in 2000 (Jones et al. 2007). With this landscape protection and care took on a global scope (Weber 2007). Globalization causes local relationships and networks to become less important, as the influence of long-distance networks increases (Swaffield and Primdahl 2006).

According to Pedroli et al. (2007) the European landscape is going through a crisis. After generations of farmers and land owners the landscape is becoming the product of nameless globalization. In this context a new identity needs to be found for it. Landscape perception is important, and not only that of the rural population, but of the population in general (Buijs, Pedroli and Luginbühl 2006). Palang et al. (2006) emphasize that in some countries of East Central Europe the relationship between the landscape and people has been lost and that this relationship is now hard to find in the era of globalization.

Cílek (2008) has described landscape perception today in Czechia, and emphasizes its importance for human psychology. But the perception of landscape by local people and tourists can be different. For the tourist, misinformation and wishful thinking create a "mental map" that does not represent reality. Along with having a possible impact on inhabitants' landscape perception and their strong regional identity, the outsiders' view might influence policy decisions and therefore the general development of a region (Solymosi 2011).

Globalization is based on the global expansion of routine production and consumption patterns (including peripheral regions) and at the same time on the concentration of power in a few global areas in the world. Woods (2007) describes the global countryside as follows:

- Productive economic sectors depend on elongated yet contingent commodity networks with consumption distanced from production.

- Corporate concentration and integration are increasing with corporate networks organized on a trans-national scale.

- The global countryside is both the supplier and the employer of migrant labour.

- The globalization is marked by the flows of tourists and amenity migrants.

- The global countryside attracts high levels of non-national property investment for both commercial and residential purposes.

- Also the construction of nature and its management is transformed within globalization. 
- The landscape is impressed through deforestation and afforestation, mines and oilfields, tourism infrastructure, the transplantation of plant and animal species, the proliferation of symbols of global consumer culture etc.

- Social polarisation increases.

- The global countryside is associated with new sites of political authority.

- The global countryside is always a contested space.

Therefore, the question is, to what extent South Moravia completes the mentioned marks of globalization. It will be sometimes not easy to divide global and international (e.g. double-sided) factors. Hypothetically, changes in the South Moravian landscape under the influence of globalization may manifest themselves in the following factors:

- The changes in agricultural land use: a decline in the traditional production of food in favor of permanent grasslands, energy crops, and in the case of South Moravia wine as well. The changes are partly evoked by the EU Common Agricultural Policy.

- The changes from agricultural land use to other types of use: afforestation, urban land use (residential and infrastructure use), energy buildings (e.g. wind turbines or solar plants).

- The changes leading to increased landscape care on the national and European level.

- The changes in recreational and amenity land use: construction of non-rural residences, facilities and trails.

It is also necessary to take into account that the landscape of South Moravia is not unique. It is differentiated according to the physical characteristics - at least for lowland and upland and also according to the geographical position - for the surroundings of the regional capital Brno and different levels of periphery consisting of inner and borderland ones. Each type of the landscape can be sensible to different aspects of the global development and in different extent.

\section{The landscape of the South Moravian Region}

\subsection{Characteristics of the region}

The South Moravian Region is located in the southeast of the Czech Republic. To the south it borders with Austria, and to the southeast with Slovakia, as well as with 5 other regions of the Czech Republic. From west to east the regions are: the South Bohemian Region, the Vysočina (Highland) Region, the Pardubice Region, the Olomouc Region and the Zlín Region. The South Moravian Region is made up of the following districts: Brno-city, Brnocountryside, Hodonín, Břeclav, Blansko and Vyškov. There are 672 municipalities in the South Moravian Region, 47 of which have a town status. The region's population is positively influenced by the presence of Brno, the second largest city in the country. The population of the region was $1,156,930$ (September 30,2011 ) over an area of 7,195 square kilometers. This means a population density of 157 inhabitants per square kilometer and if we exclude Brno, this ratio becomes 110 inhabitants per square kilometer. It is therefore a rural area according to European Union criteria. Large rural settlements with populations of more than one thousand, which are relatively far from each other, are typical for the southern part of the region. In the northern half average settlement size is less.

In the South Moravian Region there are 593 rural municipalities, if we use the National Strategic Rural Development Plan limit of 2,000 inhabitants. These make up $88 \%$ of all municipalities, and in regards to population almost $30 \%$. In total, 336,000 inhabitants live in the rural municipalities of the South Moravian Region. In the first half of the 1990s the population of municipalities of up to 2,000 decreased slightly. Since the second half of the 1990 s the population of rural municipalities has risen slightly (2\% growth between 1996 and 2004), as opposed to the entire South Moravian Region, which registered a decrease of $2 \%$. Depopulation is therefore not a general rural problem, but instead certain areas are in danger by that. Positive population developments have occurred particularly in rural municipalities concentrated around larger cities; Brno's influence is clearly at play. This is mainly a result of suburbanization. 
The intensity of these suburbanization phenomena depends on the transportation accessibility of the municipality and is often markedly selective.

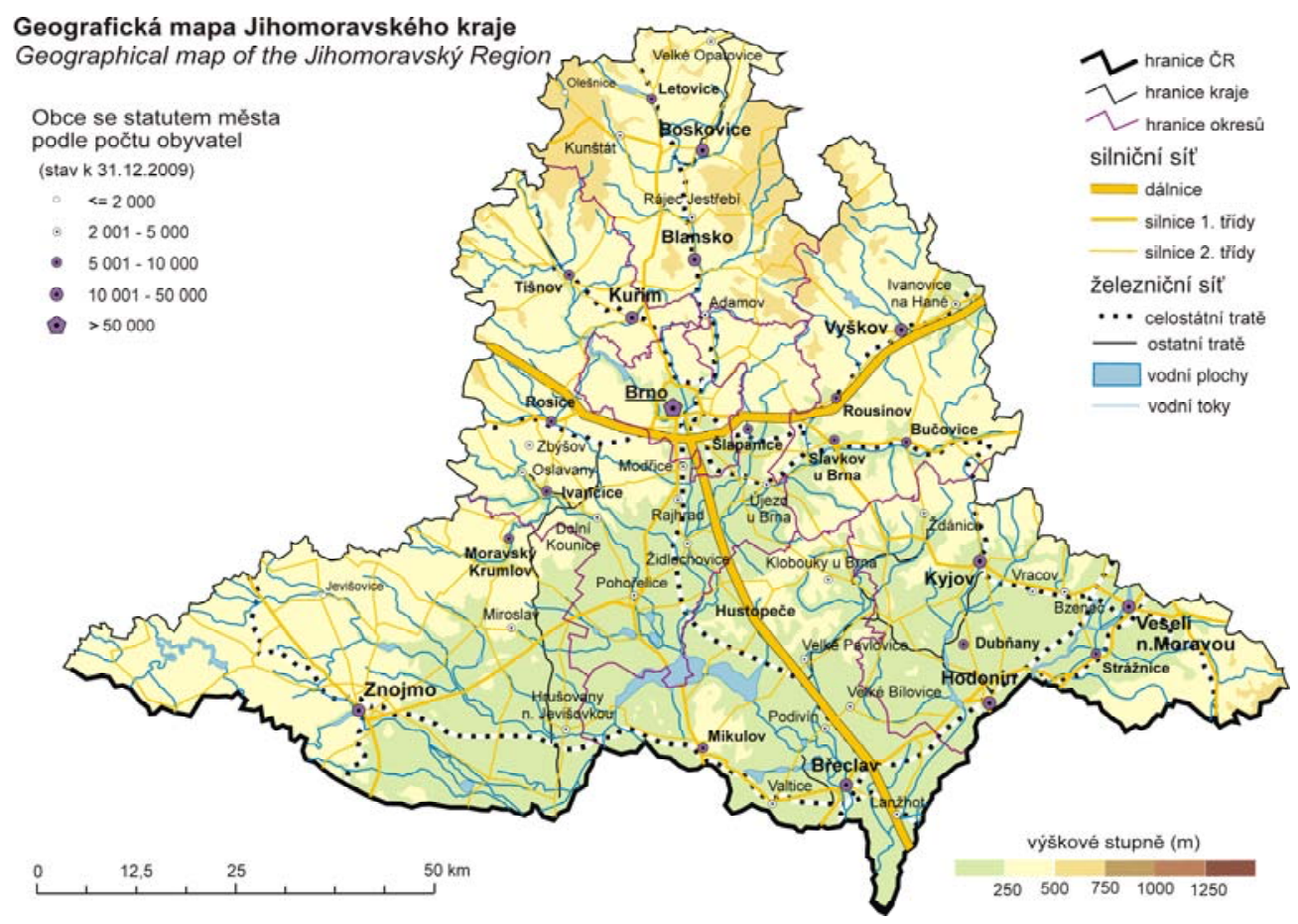

Fig 1. The South Moravian Region and its position within Czechia. Source: www.Czso.cz

Rural municipalities have recently seen a natural population loss of $2.7 \%$. This loss is compensated by a positive balance of migration (5.3\% as opposed to the region as a whole with $0.5 \%)$. The portion of the population under 15 years old is 1.2 percentage points higher in rural municipalities (17.2\%). This portion is compensated by a lower portion of the productive age population. The portion of the population above 60 years old is only inconsiderably larger. Unfavorable age structures and population aging are most prevalent in the smallest municipalities. In municipalities of up to 200 inhabitants the portion of the post-productive age population is higher than the pre-productive age population by 6.5 percentage points. These portions become closer in size as municipality size grows. For the educational structure of the population, the rural population has a significantly lower level of formal education. Although during the 1990s the overall level of education rose, the difference between rural areas and towns grew. The portion of university-educated people in rural municipalities is only $4.4 \%$. On the other hand $13.6 \%$ of the urban population has a university education, which is a large difference.

Today only a small part of the rural population works in agriculture (about a tenth to a third of the economically active population in a given municipality). In rural areas a large portion of the economically active population works in services, industry and trades, or they commute to towns and are dependent on transportation service. Industry is the main employment sector in rural municipalities with $36.3 \%$ of the working population. $32 \%$ of the working rural dwellers are employed in services. The larger the municipality is and the better served by transportation it is, the portion of those employed in agriculture drops and the portion employed in services increases.

Unemployment in rural areas is strongly influenced by the transportation connectivity of the municipality, that is to say the level of difficulty of commuting. The unemployment rate on the district level ${ }^{4}$ varies between $6.4 \%$ in the district Brno-countryside and $13.1 \%$ in the district Hodonín. Many times cities including Brno have higher unemployment rate to compare with their rural hinterlands. But extreme cases can be found in the countryside. Several rural

\footnotetext{
${ }^{4}$ Ministry of Labor and Social Affairs, data valid for June 2009
} 
municipalities in the Znojmo District were in the worst situation in June 2009 exceeding the limit of $20 \%$ unemployment rate.

The technical infrastructure facilities (water, sewage, gas) of homes in rural areas have remained less than in towns. However, the difference in technical infrastructure facilities between rural areas and towns decreased in the 1990s. The portion of houses connected to the sewage system grows significantly with the size of the municipality. According to the 2001 census in rural municipalities as a whole $34 \%$ of houses are connected. Today the amount of rural municipalities served by water supply networks is very high and the portion of houses connected to the network is only 3 percentage points lower than in towns.

Brno, the center of the South Moravian Region is undoubtedly the second largest city in the country and the largest city in Moravia, whose central importance surpasses the region's borders. There are 371,399 permanent inhabitants ${ }^{5}$ in Brno, which represents $32.3 \%$ of the region's population; this portion has experienced long-term decline. According to data from the Police of the Czech Republic, who keep records of long-term residence, Brno has 403,360 inhabitants ${ }^{6}$ and is growing. According to estimates by Masaryk University and Charles University the lower limit of the population really present in Brno ranges between 515,000 and 534,000 people. Brno is therefore a very important center.

There are 5 other medium-sized cities in the region: Znojmo (34,752 inhabitants), Hodonín (25,526 inhabitants), Břeclav (24,164 inhabitants), Vyškov (21,847 inhabitants) and Blansko $(21,057$ inhabitants). The total population of the South Moravian Region living in medium-sized cities is therefore 127,346 , which represents $11.2 \%$. There are 17 small towns with populations between 5,000 and 20,000 in the region. Of these Veselí nad Moravou, Kyjov, Boskovice and Kuřim have populations of more than 10,000. Totally 131,188 people have permanent addresses in these towns, which means $11.5 \%$ of the region's population. Thus, $45 \%$ of the South Moravian Region's population lives in municipalities with less than 5,000 inhabitants. Although several of these municipalities are officially towns, there is no doubt about their rural nature. In this regard the region can be labeled as being relatively rural.

The South Moravian Region features a larger proportion of larger rural municipalities than the average in Czechia. Totally $17 \%$ of municipalities have a population of less than 200 in the region, but this percentage is $25 \%$ for Czechia. $47 \%$ of municipalities in the region have less than 500 inhabitants, whereas this figure is $57 \%$ for the whole country.

\begin{tabular}{|l|c|c|c|c|}
\hline Population & $1000-4999$ & $500-999$ & $200-499$ & less than 200 \\
\hline Number of municipalities & 155 & 180 & 199 & 116 \\
\hline
\end{tabular}

Tab 1. Size structure of rural municipalities of the South Moravian Region.

Peripheral rural areas can be seen as problematic. The marginality of an area is related to its transport accessibility. The majority of socioeconomic activities are concentrated in urban centers and the corridors that connect them. Mainly regions in the southwest and north of the region are included as peripheral areas. This is around Vranov nad Dyji, as well as around Miroslav, Hrušovany nad Jevišovkou and Hevlín, and municipalities to the west of Moravský Krumlov in the southwestern part of the region and marginalized municipalities north of Tišnov, in the area of Letovice and Boskovice, in the northern parts of the Moravian Karst, as well as some municipalities near the Březina Military Training Area in the northern part.

The described settlement characteristics have an influence on development trends in the South Moravian landscape. The concentration of the population into one city means a significant burden on the landscape, whereas other more scarcely populated areas mean a lower intensity of landscape use for functions other than primary.

In 2008 the contemporary South Moravian Region contributed $10.1 \%$ of the countrywide GDP, which was the fourth highest value of all 14 regions in the Czech Republic. It amounts

\footnotetext{
5 Population as of January 1, 2010. The Czech Statistical Office Prague

6 The Ministry of the Interior of the Czech Republic, data from January 1, 2009
} 
$16,866 \mathrm{PPS}^{7}$ per capita which means also the fourth place among Czech regions (first three being Prague, Central and Western Bohemia). It is more than in some more urbanized regions in the northern part of the country.

Industry is the most important sector in the region. Shifts in the structure of industrial businesses indicate a tendency to production with higher added value. Although earnings and the gross added value in industry have grown, the number of those employed has decreased. Mechanical engineering and electrical engineering have the most important positions in the region. These are followed by the textile industry, which has however been in a long-term recession. The food processing, chemical, pharmaceutical, glass, ceramic and wood-processing industries are also of certain importance. Foreign investors most frequently direct their investments to Brno and Modřice, which feature the highest profile industrial zones. Changes in the structure of industry have meant on one hand a reduction of negative environmental impacts on the landscape, while on the other hand new industrial zones have taken up relatively expansive areas.

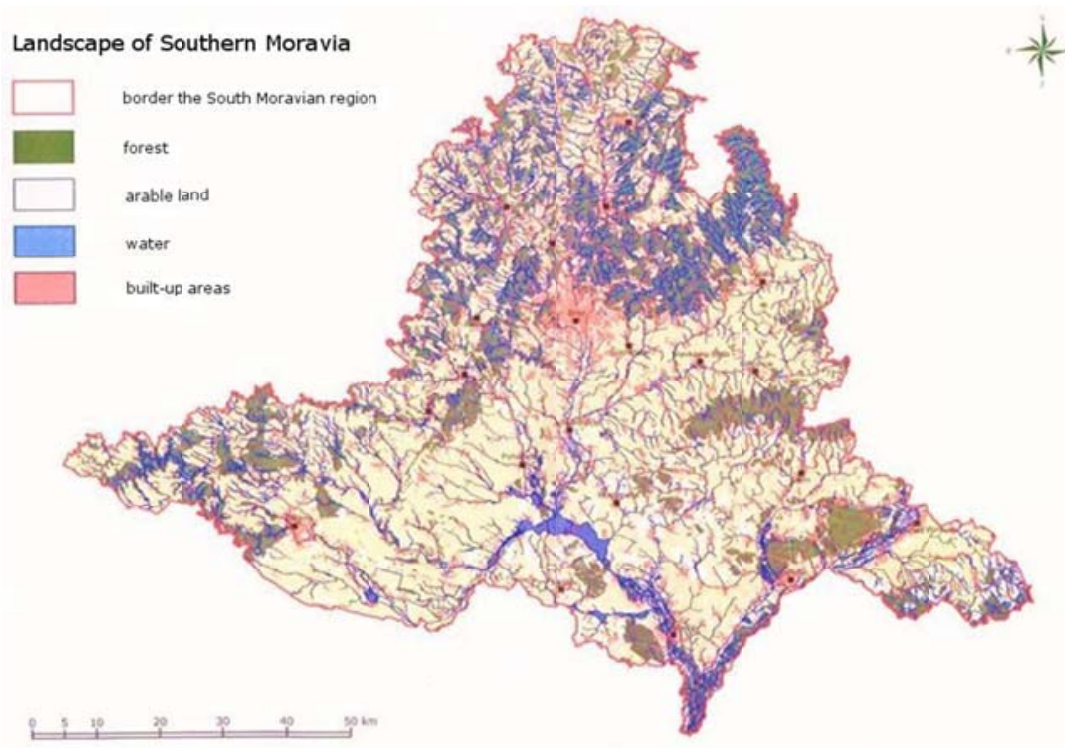

Fig 2. Landscapes of South Moravia. Source: South Moravian Regional Office, Department of Environment 2009.

\begin{tabular}{|l|c|c|c|}
\hline Land use & $\mathbf{2 0 0 2}$ & $\mathbf{2 0 0 9}$ & $\mathbf{2 0 0 9} \%$ of 2002 \\
\hline Agricultural land & 434 & 428 & $\mathbf{9 8 , 6}$ \\
\hline$-\quad$ Arable land & 364 & 355 & 97,5 \\
\hline$-\quad$ Gardens & 16 & 16 & 100,0 \\
\hline - Orchards & 10 & 9 & 90,0 \\
\hline - Vineyards $\quad$ Pastures and grasslands & 14 & 18 & 128,6 \\
\hline Forests & 30 & 30 & 100,0 \\
\hline Water areas & 201 & 202 & 100,5 \\
\hline Built-up areas & 15 & 15 & 100,0 \\
\hline Others & 14 & 14 & 100,0 \\
\hline Total & 55 & 60 & 109,0 \\
\hline
\end{tabular}

Tab 2. Land use in 2002 and 2009 [thousands of ha]. Source: Czech Statistical Office Praha

\footnotetext{
7 PPS purchasing power standard (EUR)
} 
Agriculture contributes $3.6 \%$ of the region's total gross added value. This seemingly low contribution is a result of the agricultural economy not being comprehensively perceived. Agriculture and forestry, in comparison with other segments of the economy, are specific for their close bond with biological processes. The fact that in the region the ratio of agricultural land to total area is large, as it exceeds $60 \%$, has great significance for the position of agriculture not just in the region's economy. Arable land makes up $50.9 \%$ of the area of the territory of the South Moravian Region (39.0\% in Czechia), which is of basic importance for landscape changes. Besides standard agricultural production the region, in comparison to other Czech regions, is set apart by its important fields of specialized production, fruit growing and viniculture in particular. Fish production is not minor either. In recent years, however, livestock production has undergone a large decline, especially cattle breeding.

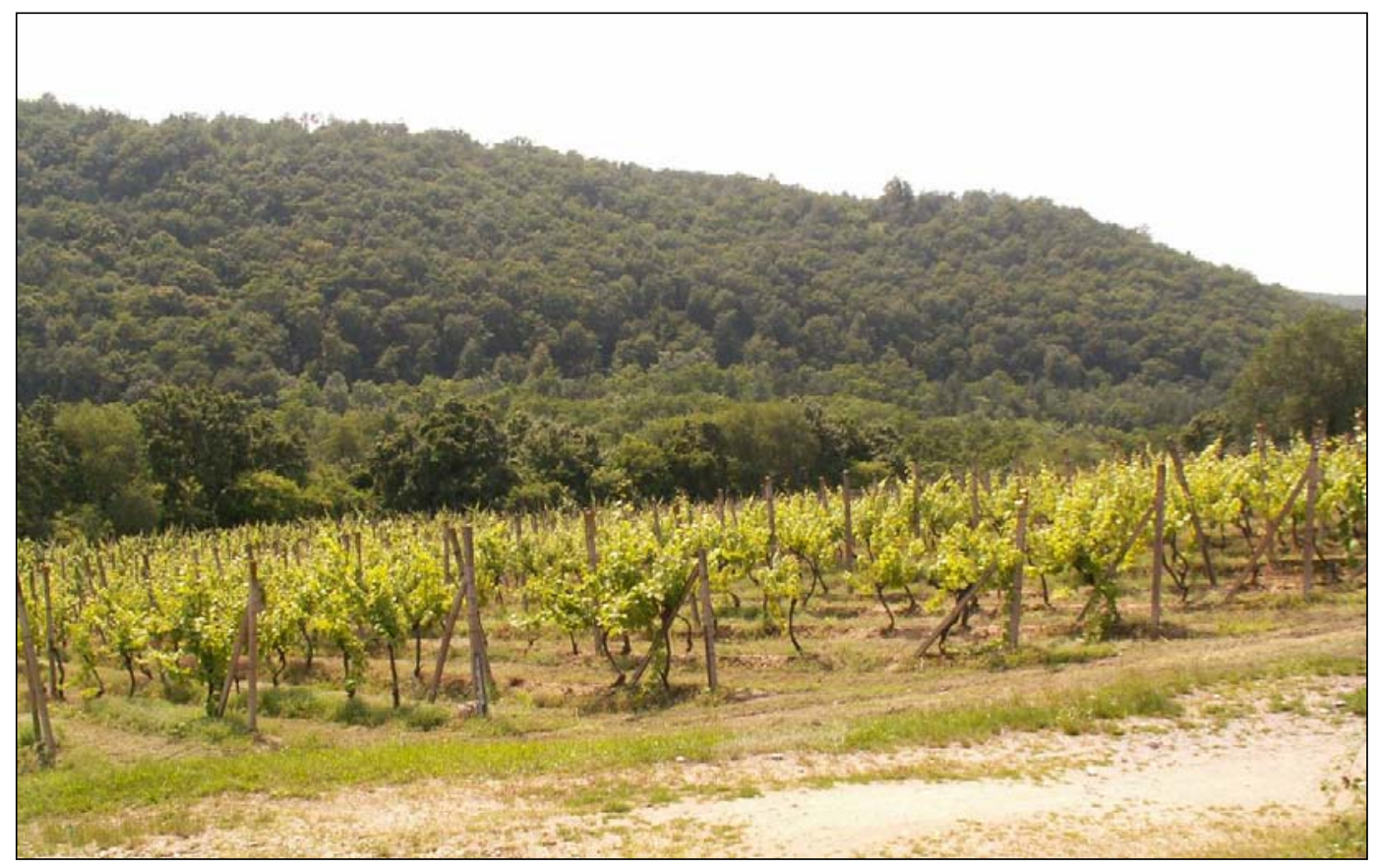

Fig 3. Vineyards and orchards are related to typical agricultural activities in South Moravian region. Photo T. Mašíček

The average percentage of forest land was only $28.1 \%$ in 2003 , which was less than the countrywide average (33.5\%). Currently, the position of agriculture and forestry in relation to environmental conservation and formation is noticeably changing. Water sources, especially potable, whose strategic importance for the development of civilization has potentially the same significance as energy sources, are featured in the landscape. Their activity dominantly affects agriculture and forestry. The growing demand of the urban population for spaces for relaxation and recreation in the rural landscape is to a large extent the affair of farmers and foresters. Henceforth, for many reasons, it is unavoidable to perceive the position of agriculture and forestry in the South Moravian Region in a fundamentally more comprehensive manner than has been usual. The perspectives for South Moravian agriculture and forestry will also be formed by the transformed Common Agricultural Policy of the EU, which incorporates integrated agricultural and rural development.

All forms of territorial legal protection, from national parks to small-scale specially protected areas, are found in the South Moravian Region. In total the region features 1 national park (Podyjí), 3 protected landscape areas: Moravský kras (Moravian Karst), Bílé Karpaty (White Carpathian Mts.), and Pálava (Pavlovské vrchy Hills) - the last two are UNESCO biosphere reserves as well) and 280 small-scale specially protected areas. In 2003 the Pálava Biosphere Reservation was expanded to include the Lednice-Valtice area, and Podluží and its floodplain forests in the area between Břeclav, Mikulčice and the confluence of the rivers Morava and Dyje (this area bears the new name of the Dolni Morava Biosphere Reservation). The number of natural parks is also significant, as currently 20 have been declared on the territory of the South Moravian Region. 


\subsection{Changes in agricultural land use}

The South Moravian Region is one of the most productive agricultural areas in Czechia. There are 363,000 ha of cultivated agricultural land, of which $90 \%$ is arable land. Almost half of the agricultural land $(47.2 \%)$ is located in the maize production area. In order the second most significant production area is the beet area (36.7\%). $12.3 \%$ of agricultural land is located in the potato production area, $3.4 \%$ in the potato-grain area and $0.4 \%$ in the mountain area. The region's specialized agricultural production is oriented towards growing fruit and viniculture. More than a fifth of all fruit orchards in the entire country are also located in the region. In area there are 15,000 ha of vineyards and they represent $92 \%$ of the vineyards in Czechia. Their area grew right before the establishment of new vineyards was prohibited pursuant to EU regulations.

\begin{tabular}{|l|c|c|c|}
\hline Plant & 2007 & 2008 & 2009 \\
\hline wheat & 514 & 646 & 610 \\
\hline barley & 209 & 281 & 238 \\
\hline industrial sugar beet & 249 & 287 & 280 \\
\hline potatoes & 43 & 50 & 46 \\
\hline rape & 72 & 87 & 96 \\
\hline green and silage maize & 402 & 456 & 391 \\
\hline lucerne & 95 & 86 & 93 \\
\hline market vegetable & 42 & 41 & 48 \\
\hline fruits & 25 & 33 & 34 \\
\hline
\end{tabular}

Tab 3. Harvest of the most important plants 2007 - 2009 [thousands of tones]. Source: Czech Statistical Office Praha

Global influences have manifested themselves in South Moravia as well, and have meant a drop in agriculture's production function. However, considering the excellent natural conditions these changes are not as significant as in other areas. The transformation of arable land to permanent grasslands (which take up an area of 19,000 ha) has occurred mainly in less fertile areas of the region in the Blansko district. Another type of change is organic farming. This though is not very developed in the South Moravian Region, as it has developed mainly in regions with worse natural conditions. In total 4,900 ha (2007) are farmed organically in the region. In 2007 a total of 708 ha of agricultural land lay fallow.

Overall trends in Czech agriculture indicate that sowing areas of most crops are decreasing. Rape seed and several other oil seeds (e.g. poppy), grain maize and grape vines are exceptions. In the case of grape vines the area under cultivation grew by $46 \%$, whereas the harvest grew by $175 \%$. Main grain harvests have risen slightly, despite the fact that the area under cultivation has declined, for the yield per hectare has grown. The sowing areas, as well as harvests, of potatoes and sugar beet have decreased markedly.

The Czech agriculture does not operate under market conditions but under subsidies and limits of the Common Agricultural Policy of European Union which deforms the market substantially. One of the impacts of the former collectivization is contemporary predominance of large agricultural producers over family farms which are supported by the CAP. Industrialization and modernization of the Czech agriculture within the central planned economy resulted in a relatively high efficiency and competition ability which manifested after opening of market barriers in 1990s (Věžník, Konečný, Svobodová, 2009). But the Czech agriculture became a part of European agriculture under very inconvenient conditions in 2004 . It could be documented by contingents of individual commodities and lower direct payments to compare with the conditions in the EU-15 countries (Svobodová 2010). 


\begin{tabular}{|l|c|c|c|}
\hline Plants & $\mathbf{2 0 0 0}$ & $\mathbf{2 0 0 8}$ & \% of $\mathbf{2 0 0 0}$ \\
\hline Cereals & 220,2 & 221,5 & 100,6 \\
\hline Pulse crops & 4,0 & 4,4 & 110,0 \\
\hline Potatoes & 6,6 & 2,2 & 33,3 \\
\hline Industrial sugar beet & 6,2 & 5,3 & 85,5 \\
\hline Oil plants & 58,3 & 53,4 & 91,6 \\
\hline Fodder crops & 51,1 & 31,6 & 61,8 \\
\hline
\end{tabular}

Tab 4. Acreages of the main groups of plants in 2000 and 2008 [thousands of tones]. Source: Czech Statistical Office Praha

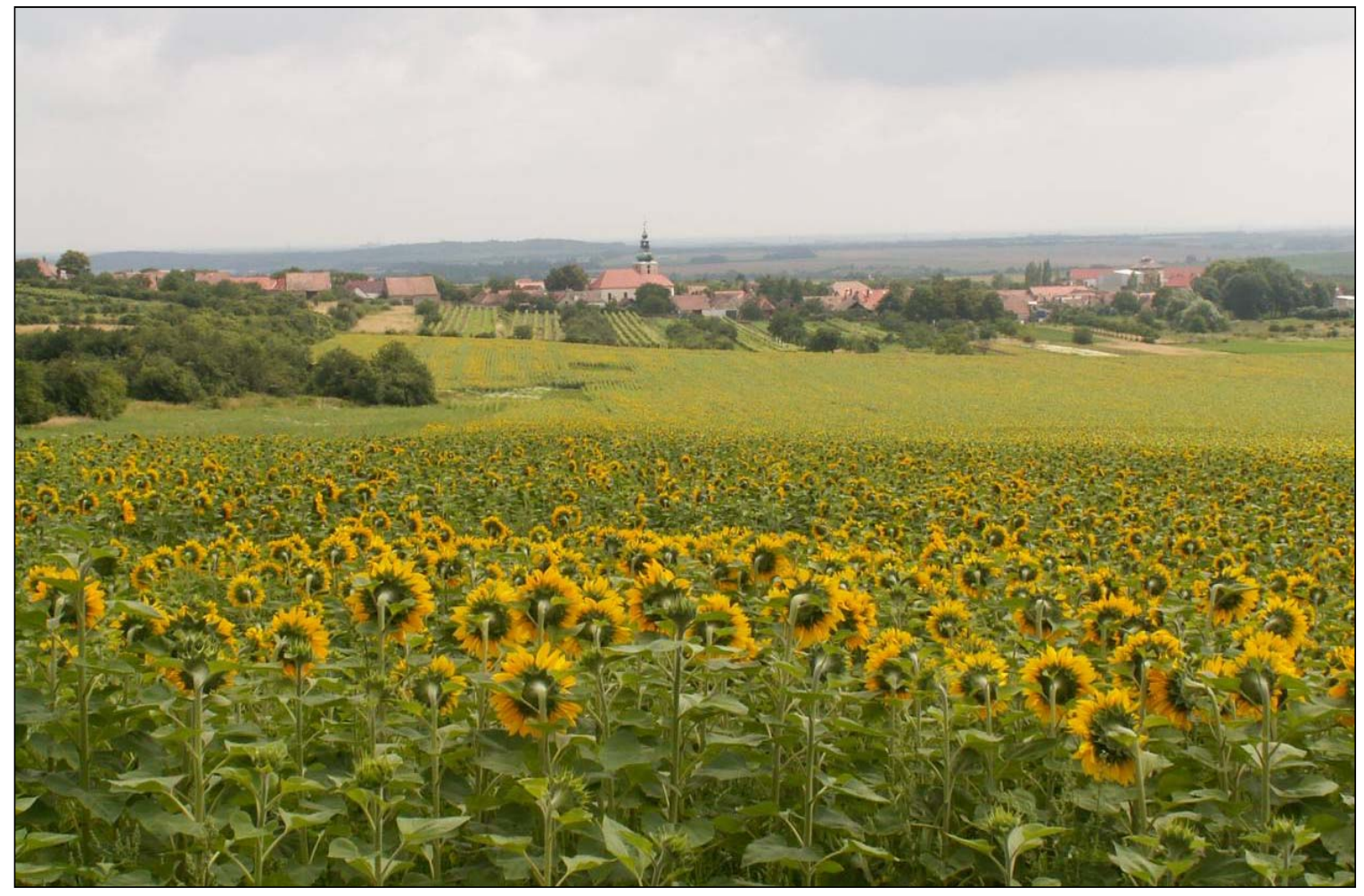

Fig 4. Rural landscape in the district of Znojmo. Photo T. Mašiček

Sowing area development in the period 2002-2008 did not completely follow countrywide trends. There were decreases in the sowing areas of winter wheat (to 92\%), industrial sugar beet (to $55 \%$ ), silage maize (to $68 \%$ ), fodder crops (to 68\%) and surprisingly rape (to $80 \%$ ). On the other hand the sowing areas of spring barley, grain maize (to $158 \%$ ), forage crops and the area of vineyards have grown. Thus, it seems that to a certain extent the South Moravian Region has stayed at the same level of grain and grape production and has not completely succumbed to the trend of changing to energy crop production. This is so despite the fact that harvests of individual crops in the South Moravian Region are not higher than in other regions ${ }^{8}$. Tradition may play a role here. The decrease in sugar beet production is given by the decision of the European Union on sugar production quotas.

Another type of changes comes into the question in connection with the ownership changes of agricultural enterprises. In the South Moravian Region, 36\% of agricultural land is farmed by joint stock companies, $22 \%$ by limited liability companies, $21 \%$ by cooperatives and $20 \%$ by natural persons (2008). The average size of the agricultural enterprise of a natural person is 9.4 ha - the lowest in Czechia thanks to the wine growers. The average size of an enterprise of

\footnotetext{
${ }^{8}$ Opinions that have yet to be completely proven say that the fertility of the South Moravian Region may be reduced due to increasing water shortages, which could be the result of global climate change. This shows other possible global aspects of landscape change (global risks).
} 
a legal entity is 696.8 ha (the $4^{\text {th }}$ smallest in Czechia), of it joint stock companies 1,270 ha, cooperatives 1,225 ha and limited liability companies 333 ha (2008). From it follows that large fields of cereals are typical also for the South-Moravian landscape to compare it with neighbouring Austria.

A fundamental problem is the location of owners of the dominant farms in the region. Whereas on former collective farms, despite centralized control, their management was firmly founded in the local area and had a certain interest in preserving the landscape's qualities and its production potential, farm management today may be located in faraway cities or even abroad. Moreover in most cases the land is rented, and therefore is not farm property. Whereas natural persons work on their own land of $45 \%$, the legal entities farm on the leased land of $86 \%$. As opposed to collective farms, which as the dominant entity of rural municipalities as a rule invested in development, home construction, and social and technical infrastructure, far away owners have no interest in this. If they need to they can simply put their capital into other regions or even other industries. This factor may be a typical aspect of globalization with an important impact on the landscape among others.

\subsection{Changes from agricultural land use to other types of use}

Forestry is an alternative to agriculture. The arrangement of forests is extremely uneven with a higher concentration in the north particularly on the territory of the Březina Military Training Area. Despite this, one of the most valuable floodplain forest ecosystems is located in the region at the confluence of the Morava and Dyje rivers. Decrease in agricultural production supports afforestation, but this trend is not very strong in the region.

Effects of globalization on the rural condition are often seen in exurban or metropolitan sprawl and the resulting landscape fragmentation (Hamin and Maecucci, 2008). Suburbanization has incurred very significant landscape changes. Suburbanization has had a residential, manufacturing, logistical and commercial character. A part of these changes has included the construction of roads including motorway intersections. One of the first areas to be largely suburbanized in Czechia, and the most expansive suburban area in the region, is the area south of Brno at the intersection of motorway D1 (Prague - east of the country), motorway D2 (Brno - Bratislava) and regional motorway R52 (the future Brno - Vienna motorway). These changes stand out all the more, as unattractive suburban buildings have been built on agricultural land of the highest quality. The question is whether or not in the future food security will be a problem again. In such a case the described changes would have to be considered exceptionally undesirable.

On the other hand brownfields could be found in the rural landscape, although their area is not very large. These are former large-scale agricultural buildings, military sites (particularly on the state border), no longer used railway tracks and stations, as well as small industrial sites such as distilleries, etc. These sites, whose number in the region is estimated to be up to 1,300 , rather disfigure the contemporary landscape, and their utilization is often problematic, especially when ownership is not fully clear.

The construction of solar and wind power plants is under consideration in the region in relation to the search for alternative energy sources. The current wind farms in Bošovice, Klobouky, Násedlovice, Nenkovice, Vrbice and Stavěšice are situated in the specific Pannonian rural field landscape, whose current landscape character developed through millennia of agricultural cultivation. The helter-skelter construction of wind farms in the South Moravian rural landscape should be avoided. Wind farms must absolutely not be constructed where biodiversity and specific landscape character is protected, i.e. in areas falling under the categories of specially protected area, NATURA 2000, wetlands of international importance in accordance with the Ramsar Convention and component elements of territorial system of ecological stability of the landscape (Buček 2007). 


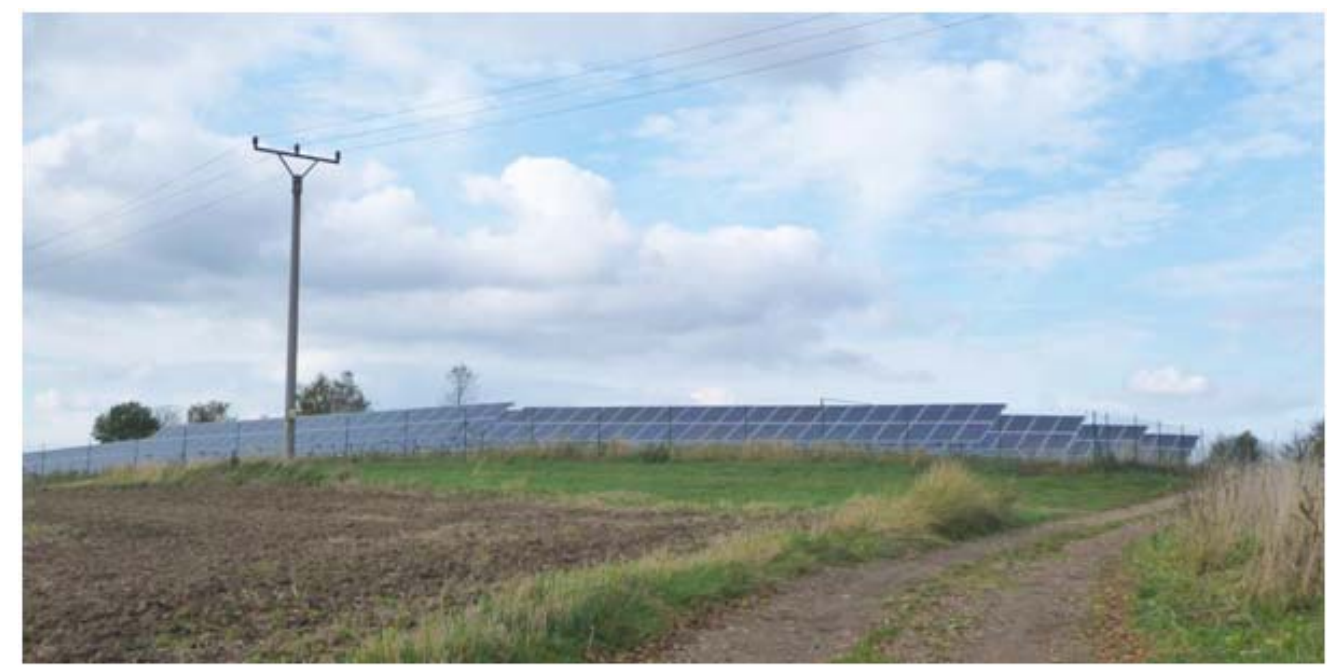

Fig 5. Photovoltaic plants manifest a new element in the South-Moravian landscape. The case from Blansko district. Photo A. Vaishar

Photovoltaic plants recorded a boom in the last two or three years - thanks to the incorrectly adjusted legislation. Their capacitance has multiplied in the mentioned period. $7.5 \mathrm{GWh}$ of power was produced in photovoltaic plants nationwide in October 2010 which is 8.5 times more than in October 2009. South Moravian Region has the best conditions for the power production from the sun amongst all Czech regions.

The plants often occupy large plots of originally arable land in such an extent that they start to manifest a frequent landscape feature. The massive support of such plants has finished in 2010. It is presupposed that photovoltaic equipment will develop mostly on roofs, buildings and technical areas in the near future. It is possible to expect some brownfields after abandoned solar power plants in the future.

Although the most valuable parts of the South Moravian landscape have been protected for a long time, currently the changes in its protection under the patronage of the European Union have made significant changes. This is mostly due to the fact that two out of the three protected landscape areas have attained the status of UNESCO biosphere reserve. NATURA 2000 bird sites also have an important role. South Moravia also features an artificial landscape which is on the UNESCO world heritage list: the Lednice-Valtice area. With this, the landscape has become a part of the global tourism industry.

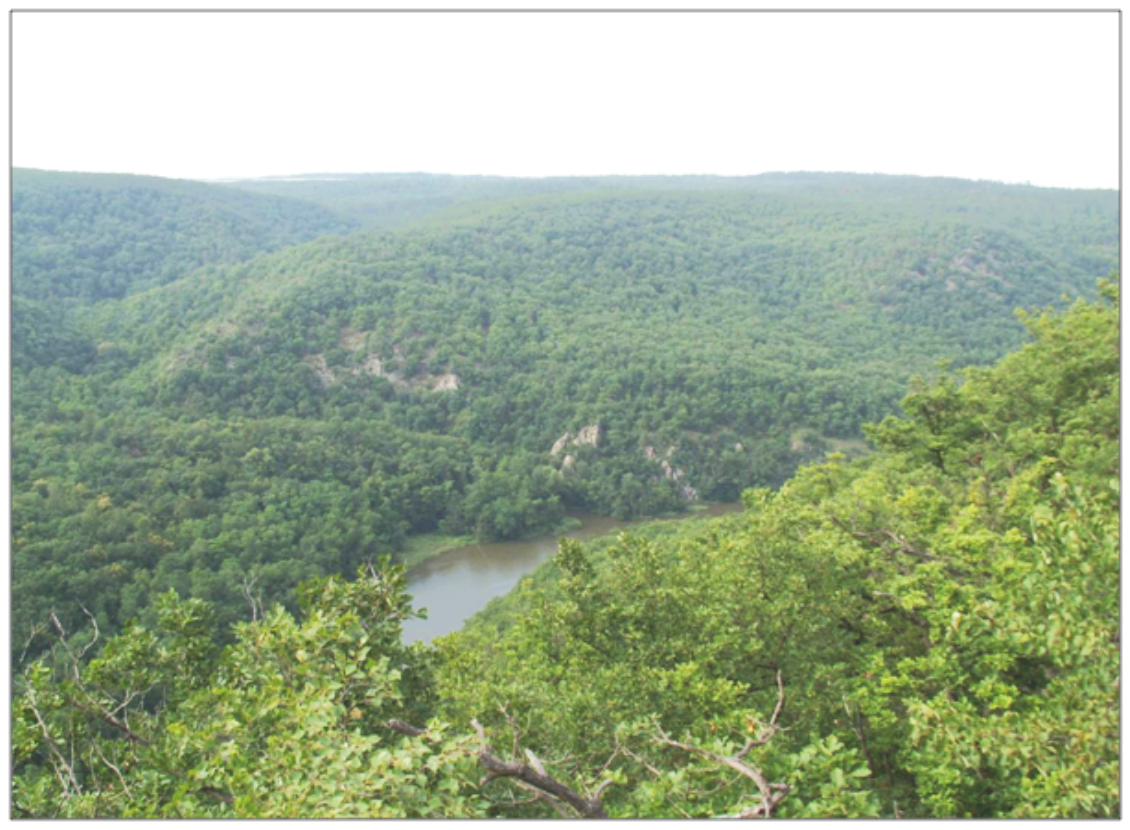

Fig 6. Canyon of the Dyje river in the Podyji National Park. Photo T. Mašíček 


\subsection{Changes emphasizing recreational landscape use}

According to Whatmore (1994), rural landscapes are commoditized in the leisure, tourist and residential development industries. A majority of rural development programs emphasize the development of recreation and tourism. Sooner or later these changes are reflected in the landscape. Currently these changes are not fundamental on the regional scale. Recreational sites, pensions and bicycle trails supplement landscape character. A relatively significant part of recreation in the region is connected to wine culture and living folk traditions. Thus, some agriculture has become commercialized and is aimed at tourists, which becomes apparent with a more detailed look (e.g. lodgings being built above wine cellars). It can be assumed that tourism has had a more intense impact on the South Moravian Region's landscape in the Moravian Karst area, where several valleys had to be closed to automobile traffic.

Large reservoirs that were created in the course of the $20^{\text {th }}$ century represent a relatively large interference in the landscape. The Nové Mlýny reservoir, whose main purpose was to be used for irrigation, is often considered controversial. This reservoir was criticized especially for the permanent flooding of very valuable floodplain forests. Today, however, it is an inseparable part of the South Moravian landscape and is used, among other things, for recreation, although limited by water quality. It is the most famous recreational fishing location in the region. The middle reservoir is a water fowl reserve. The silhouette of the Pavlovské vrchy Hills and the reservoir form together an attractive dominant feature of the landscape, which is the most often portrayed segment of South Moravia's landscape. Its surroundings are interspersed with bicycle paths. Although nature conservationists keep criticizing it, the reservoir is an important attraction especially because a water recreation is supplemented by wine culture and folk traditions, as well as trips to the Pavlovské vrchy Hills, or even to farther off historical town Mikulov or the Lednice-Valtice area. Thus, it is one of the few South Moravian landscapes that offer relatively comprehensive tourist opportunities.

The Vranov water reservoir built in 1930's and Brno water reservoir (1940's) struggling with the deteriorating water quality are other most known water areas among many others. There are also some large and small fish ponds forming the South Moravian landscape and creating the mosaic of fields, forests, villages and water areas so attractive for tourist use.

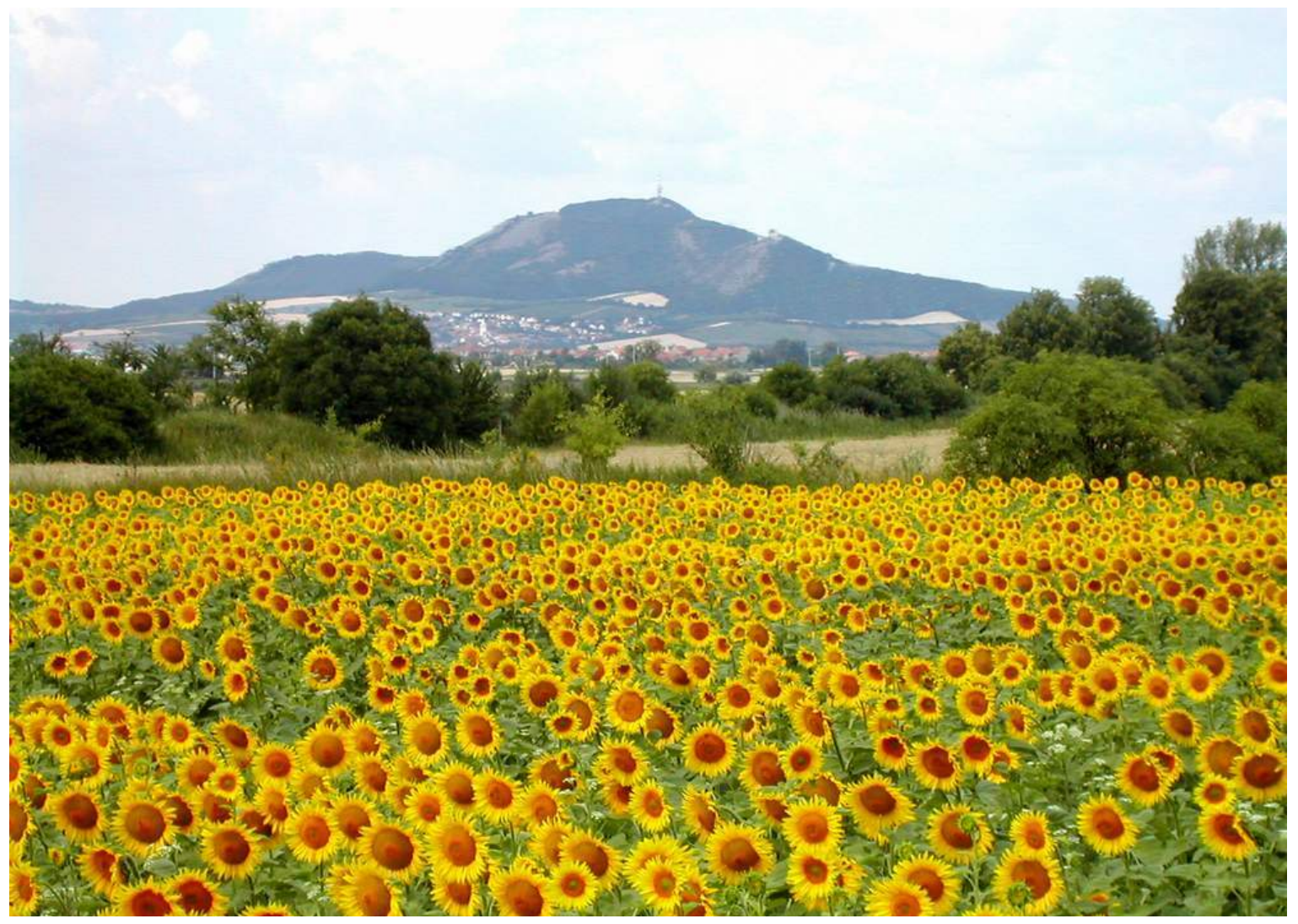

Fig 7. Pavlovské vrchy Hills dominate the landscape in the Moravian - Austrian border. Photo P. Trnka 
The main "tourist product" to offer is surely the cultural landscape of the South Moravian Region itself, and its seemingly inconspicuous dominating features. This landscape by itself has a great potential for tourism. There is a high level of cultural and social stability, which forms the base of regional values. The beauty of this landscape needs to be sought out - it does not stand out as much as the nearby Alps. However, living folk culture in relation to the landscape gives the region a special position in the entire Czechia and deserves an extraordinary level of protection and support.

\section{Discussion}

The scenery of the South Moravian Region has undergone millennia of development from primitive cultivation to industrialization and urbanization. This all took place in relation to changes in social values and ways of life. Today's accelerating industrial and financial globalization is a further step in its development.

The questions of course are: Which of the above described can be considered a result of globalization's influence? How the mechanisms of these influences work? What are the perspectives for development? Considering globalization's ambiguity (the rapid transfer of advanced technology versus the danger of identity loss) it is necessary to discuss the question of strengthening the South Moravian rural identity in a globalized environment.

It seems that the globalization of the South-Moravian landscape is caused by two main circumstances. The Common Agricultural Policy of EU is the first of them. Its financial subventions are often more important than realistic market milieu. European agricultural policy will have to change its rules. So, the expected impacts of global decision could also change the Moravian landscape in the future. The opening to the worldwide rural market is another main point. Many changes and impacts in this field are expected.

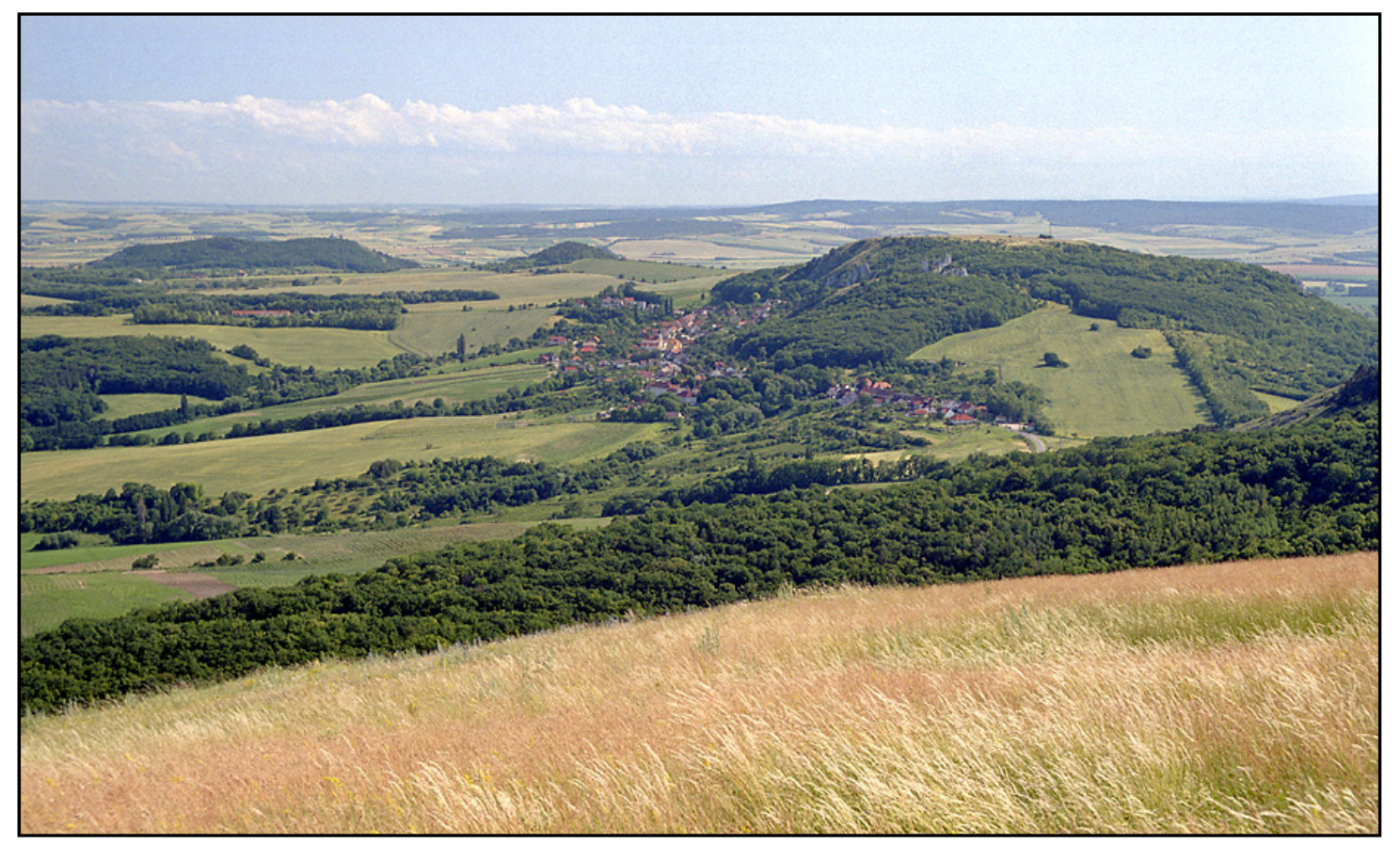

Fig 8. The South Moravian landscape: the view from the Pavlovské vrchy Hills to the south. Photo P.Trnka

It is becoming apparent that the marked changes in the South Moravian landscape are not very desirable. This landscape itself creates an important value and represents an irreplaceable part of the South Moravian Region's "rural" identity. It has significant production potential in its important parts and in the future may be important in regards to the food security. On the other hand the landscape of peripheral parts of the region is valuable for its biodiversity, and cultural and educational values. Certain changes resulting from new technologies are essential, but they should be kept to a necessary scale. Although a return to the period of mosaic use within family 
farms is unrealistic, the landscape should be improved within the framework of territorial systems of ecological stability.

Some of the present trends are controversial. Let us mention the occupation of often the most fertile soil for urban and suburban constructions including highways and high speed railways or opening the landscape to the energetic equipments like solar and wind power plants. Likewise conflicts between large-scale landscape protection and regional (local) development are topical. Market economy without attributes which is realized by the Czech right-wing governments leads to the predominance of the short-time and individual economic interests. Additionally, the Common Agricultural Policy" only simulates free market. Many of the Green politics lead to the one-side enforcing of the protection. Many times it happens that the "economic" interests are not economic at all, whereas the protection leads to anti-environmental consequences. Additionally, local people often understand the economy and the protection differently from the politics on the national or European level. All these contradictions should be solved in the complicated melting pot of economic and political interests on different regional levels.

It is also necessary to take into account the fact that the Czech-Austrian borderlands lost their original population after World War II. This factor has restricted the relationship to the landscape, which takes generations to build, throughout the entire Czech borderlands (except for the Moravian-Slovak part). Although this has not affected South Moravia as intensely as Bohemia, building a new relationship to the landscape is a matter of generations.

It is possible to discuss whether South-Moravian countryside is still post-socialist (postcommunist, post-Soviet). Undoubtedly, the socialist past has manifested in some characteristics of the Czech landscape, e.g. large fields, big acreage of farms, not very familiar relation between the people and the land. But the change from the centrally planned to the market economy passed more than 20 years ago. In our opinion, the Czech agriculture can be characterized as more post-productive than post-socialist at the present time. Its impact on the landscape results preliminary from this fact.

Globalization, despite its progressive benefits, represents a certain risk to the South Moravian Region. The basic problem is the fact that landscape use is being unified under globalization, whereas decision making processes are becoming more centralized. Prevention is possible only to a limited degree, as it is often in conflict with the economic interests of businesses. Too much resistance to globalization could lead to economic marginalization, whereas falling too much under the influence of globalization could cause a loss of identity, motivation and relationship to the landscape, which were hard gained in the South Moravian borderlands after the war.

For these reasons it is necessary to systematically monitor the changes underway and put them into context with global development. We see the practical importance of the contact with important subjects in practice.

\section{Acknowledgement}

This paper is one of the results of a project entitled "Developing Europe's Rural Regions in the Era of Globalization", which is part of the $7^{\text {th }}$ Framework Programme of the EU under project number 225204. The project is coordinated by Aberystwyth University in Wales (by M. Woods), and Mendel University in Brno is responsible for creating a case studly of the South Moravian Region as well as disseminating the results of the entire project.

References

[1] Antrop, M. (2004). Landscape change and the urbanization process in Europe. Landscape and Urban Planning 67(1-4), 9-26. Doi:10.1016/S0169-2046(03)00026-4.

[2] Bičík, I. \& Jančák, V. (2003). The changes of rural space in Czechia in the period of transformation 1990-2015. Acta Universitatis Carolinae, Geographica 38(1), 11-20. 
[3] Blacksell, M. (2010). Agriculture and landscape in the $21^{\text {st }}$ century Europe: the postcommunist transition. European Countryside 2(1), 13-24. Doi: 10.2478/v10091-010-0002-8.

[4] Buček, A. (2007). Větrné elektrárny a jihomoravská venkovská krajina. In Větrné elektrárny v Jihomoravském kraji (pp. 13-14). Brno: Ekologický institut VERONICA.

[5] Buijs, A.E, Pedroli, B. \& Luginbühl, Y. (2006). From hiking through farmland to farming in a leisure landscape: Changing social perceptions of the European landscape. Landscape Ecology 21(3), 375-389. DOI: 10.1007/s10980-005-5223-2.

[6] Cílek, V. (2008). Krajiny vnitřní a vnější. $2^{\text {nd }}$ ed. Praha: Dokořán.

[7] Clout, H. (2006). Rural France in the new millennium: change and challenge. Geography 91(3), 205-217.

[8] Flekalová, M. \& Trnka, P. (2007). Landscape character assessment (case study of the Hustopeče Cadastral Area, South Moravia, Czech Republic). Moravian Geographical Reports 15(4), 13-24.

[9] Giarchi, G. G. (2007): Challenging welfare issues in the global countryside. Malden: Blackwell.

[10] Harmin, E.M. \& Marcucci, D.J. (2008). Ad hoc rural regionalism. Journal of Rural Studies 24(4), 467-477. DOI: 10.1016/j.jrurstud.2008.03.009.

[11] Helming, K., Wiggering, H. (2003): Sustainable development of multifunctional landscapes. Berlin: Springer.

[12] Hill, J., Gale, T. (2009): Ecotourism and environmental sustainability. Farnham: Ashgate.

[13] Jones, M., Howard, P., Olwig, K., Primdahl, J. \& Herlin, I.S. (2007). Multiple interfaces of the European Landscape Convention. Norsk Geografisk Tidsskrift 61(4), 207-216. DOI: $10.1080 / 00291950701709176$.

[14] Kopecká, M. (2004). The landscape-ecological plan in the process of rural landscape development supported by SAPARD. Geographia Polonica 77(2), 63-78.

[15] Łowicki, D. \& Mizgajski, A. (2005). Zmiany krajobrazu kulturowego Wielkopolski w okresie transformacji (1989-2000) i opisujace je kategorie użytkowania terenu. Przeglad geograficzny $77(4), 551-568$.

[16] Mander, Ü., Wiggering, H. \& Helming, K. (2007). Multifunctional land use. Berlin: Springer.

[17] Palang, H., Printsmann, A., Gyuró, E.K., Urbanc, M., Skowronek, E. \& Woloszyn, W. (2006). The forgotten rural landscapes of Central and Eastern Europe. Landscape Ecology 21(3), 347-357. Doi: 10.1007/s10980-004-4313-x.

[18] Palang, H., Sooväli, H., Natrop, M. \& Setten, G., eds. (2004). European Rural Landscapes: Persistence and Change in a Globalising Environment. Dordrecht: Kluwer.

[19] Pedroli, G.B.M., van Elsen, T. \& van Mansfelt, J.D. (2007). Values of rural landscape in Europe: inspiration or by-product? NJAS- Wageningen Journal of Life Sciences 54(4), 431447.

[20] Potter, C. (1986). Processes of countryside change in lowland England. Journal of Rural Studies 2(3), 187-195. Doi: 10.1016/0743-0167(86)90003-3.

[21] Soini, K. (2004): Between insideness and outsideness - studying locals' perceptions of landscape. In Palang, H., Soovälli, H., Natrop, M., Setten, H. (Eds.), European rural landscapes: persistence and change in a globalising environment (pp. 83-98). Dordrecht: Kluwer.

[22] Solymosi, K. (2011): Landscape Perception in Marginalized Regions of Europe: The Outsiders' View. Nature + Culture 6(1), 64-90. Doi: 10.3167/nc.2011.060104.

[23] Strategie rozvoje Jihomoravského kraje (2006) Brno: GaREP, Vysoké učení technické. 
[24] Svobodová, H. (2010): Dopady společné zemědělské politiky EU na možnosti rozvoje zemědělství kraje Vysočina [Theses]. Brno: Masaryk University.

[25] Swaffield, S. \& Primdahl, J. (2006). Spatial concepts in landscape analysis and policy: Some implications of globalisation. Landscape Ecology 21(3), 315-331. Doi: $10.1007 / \mathrm{s} 10980-004-4414-6$.

[26] Tapiador, F. J. (2008). Rural Analysis and Management. Berlin: Springer.

[27] Věžník, A., Konečný, O. \& Svobodová, H. (2009): Analýza dotačních možností zemědělců ČR. In Geografické informácie 13 (pp. 116-122). Nitra: Univerzita Konštantína Filozofa.

[28] Weber, M. (2007). Evropská úmluva o krajině a možnosti její implementace v oblasti koncepčních a plánovacích nástrojů pro realizaci krajinných politik. Urbanismus a územní rozvoj 10(1), 42-46.

[29] Whatmore, S. (1994): Global agro food complexes and the refashioning of rural Europe. In Amin, A. \& Thrift, N. (eds.), Globalization, institutions and regional development in Europe (pp. 46-67). Oxford: Oxford University Press.

[30] Wiggering, H., Ende, H.-P., Knierim, A., Pintar, M., eds. (2010): Innovations in European rural landscapes. Heidelberg: Springer.

[31] Woods, M. (2005). Rural geography. London: Sage.

[32] Woods, M. (2007): Engaging the global countryside: globalization, hybridity and the reconstruction of rural place. Progress in Human Geography 31(4), 485-507. Doi: $10.1177 / 0309132507079503$.

[33] Wylie, J. (2003). Landscape, performance and dwelling: a Glastonbure case study. In Cloke, P. (Eds.), Country Visions (pp.136-157). Harlow: Pearson. 